\title{
Ingen anke mot naturlege Olvik
}

Den såkalte Olviksaken var en gjenganger i Tidsskriftet i 1909 (29: 31, 124-6, 181-2, 189-91, 203-4, 928). Det dreide seg om fotograf Ole Olvik (1858-1924), som drev som «naturlæge» på Vestlandet. Høsten 1908 ble han frikjent for overtredelse av tuberkuloseloven i Haugesunds meddomsrett. Olvik hadde en sterk stilling i lokalmiljøet, og mange oppfattet rettssaken som et sidestykke til forfølgelsen av Hans Nielsen Hauge (1771-1824) hundre år tidligere. Myndighetene var i tvil om dommen burde ankes.

\section{Olviksaken.}

Spørsmaalet om, hvorvidt denne sak skulde indbringes for lagmandsret, har av justisdepartementet været forelagt medicin a ld i r e k $\mathrm{t} ø \mathrm{ren}$.

Denne har derefter uttalt, at han anser det godtgjort, at Olvik i 2 av de 4 tilfælder, som tiltalen for meddomsretten gjaldt, har behandlet og maa ha forstaat, at han behandlet patienter, som led av smitsom tuberkulose, og at han derfor har overtraatt tuberkuloselovens bestemmelser.

Rent juridisk set finder medicinaldirektøren saaledes god grund til at forlange dommen prøvet ved lagmandsret.

Spørges der derimot om, hvad der er hensigtsmæssig og gavnlig for det offentlige arbeide til tuberkulosens bekjæmpelse, stiller saken sig efter medicinaldirektørens mening anderledes. Selv om resultatet skulde bli en fældende dom i et par av tiltalens poster, stiller det sig tvilsomt, om ikke den almindelige opinion deri mere vil se et utslag av smaalig forfølgelse fra lægernes side end bevis for, at tiltalte har overtraattt landets lov. Under disse omstændigheder finder medicinaldirektøren det heldigst, at saken ikke indbringes for lagmandsret.

Departementet har derefter erklært sig enig heri, og riksadvokaten finder heller ikke tilstrækkelig grund til at indbringe saken for en lagmandsret. 